\title{
Treatment of neonatal thrombus formation with recombinant tissue plasminogen activator: six years experience and review of the literature
}

Department of Pediatric Cardiology, Vestische Kinderklinik, University of Witten-Herdecke, Dr-Friedrich-SteinerStr 5, 45711-Datteln, NRW, Germany

J Hartmann

A Hussein

E Trowitzsch

Neonatal Intensive Care Unit and Perinatal Center J Becker

K-H Hennecke

Correspondence to: Dr Hartmann, Klinik für angeborene Herzfehler, Herz- und Diabeteszentrum NRW, Universiteit Bochum, Georgstr 11, D-32545-Bad Oeynhausen, Germany jhartmann@hdz-nrw.de

Accepted 26 January 2001

\begin{abstract}
Background-Thrombosis is a relatively rare event in children. However, many conditions in the neonatal period result in an increased risk of thrombus formation. The major risk factor is the indwelling intravascular catheter. Numerous small studies have reported experience of thrombolytic treatment for neonatal thrombotic disease with a wide range of different thrombolytic agents in various forms of administration, dosage, and duration, but no conclusions on the most effective treatment for neonates has been reached.
\end{abstract}

Objective-To assess the efficacy and safety of thrombolytic treatment of neonatal catheter related thrombus (CRT) formation with recombinant tissue plasminogen activator (rt-PA).

Method-Over a six year period, 14 neonates with CRT were treated with the same rt-PA protocol (an initial bolus of 0.7 mg/kg over 30-60 minutes followed by infusion of $0.2 \mathrm{mg} / \mathrm{kg} / \mathrm{h}$ ).

Results-Complete clot dissolution was documented in 11 patients, and partial clot lysis in two patients, leading to a patency rate of $94 \%$. In two cases, local bleeding occurred, resulting in treatment failure in one case. Finally, antithrombin III substitution was required in one case. No other complications such as severe bleeding were recognised.

Conclusion-With the use of close clinical and haematological monitoring on a neonatal intensive care unit combined with serial two dimensional colour echocardiography, the present rt-PA protocol was shown to be a safe and effective method of clot dissolution in neonates.

(Arch Dis Child Fetal Neonatal Ed 2001;85:F18-F22)

Keywords: thrombus; thrombolysis; blood clot; tissue plasminogen activator

Thrombosis is a relatively rare event in children. In adults the incidence of thrombotic complications increases with increasing age. ${ }^{1}$ However, in childhood, newborns are at the greatest risk of thromboembolic complications. ${ }^{2}$ The incidence of clinically apparent neonatal thrombosis in recent reports varies from 5.1 per 100000 births $^{3}$ to 2.4 per 1000 admissions. ${ }^{24}$

There are numerous clinical and environmental conditions during infancy and childhood, such as peripartum asphyxia, infant of diabetic mother, renal disease, dehydration, septicaemia, malignant or autoimmune diseases, trauma or surgery, that result in increased thrombin generation with subsequent fibrin or thrombus formation..$^{2-6}$ One of the major risk factors is undoubtedly the widespread use of indwelling intravascular catheters. The reported incidence is $13-14 \%$ in term infants, ${ }^{78}$ but rises to $64-85 \%$ in low and very low birthweight infants, ${ }^{9}$ although thrombosis prophylaxis with low dose heparin is used in probably all neonatal units when central lines are in use. Clinical outcome is often serious. $^{5} 10$

Although small catheter related thrombi (CRTs) do not usually cause a problem if the line is simply removed, there is general agreement that treatment is needed in cases of large and fragile CRTs, because of the risk of embolism. This is particularly high in persistent ductus arteriosus and persistent foramen ovale. Treatment varies from centre to centre, with a wide range of administration, dosage, and duration of treatment, and different thrombolytic agents-for example, streptokinase, urokinase, and recombinant tissue plasminogen activator (rt-PA).

rt-PA offers several theoretical advantages to the newborn infant, including short half time, minimal antigenicity, direct activation of plasminogen, lack of inhibition by $\alpha_{2}$ antiplasmin, and localisation of fibrinolytic activity. ${ }^{11} 12$ The literature on thrombolytic treatment with rt-PA for neonatal thrombotic disease contains numerous reports of single cases and small series, ${ }^{312-18}$ but no conclusions about the efficacy and safety of thrombolytic treatment in neonates can be drawn.

The aim of this study was to assess the efficacy and safety of a thrombolytic treatment for neonatal CRT, using a standardised rt-PA protocol.

\section{Materials and methods}

STUDY DESIGN

Over six years, all neonates in a critical condition - for example, severe neonatal sepsis, prolonged asphyxia, severe respiratory distress syndrome, see also table 2-who developed CRT were matched for possible fibrinolytic treatment. The diagnosis of formation of an intracardiac or great vessel thrombus was established by two dimensional echocardiography (see example in fig 1) and clinical examination in 14 neonates. All patients were monitored in the neonatal intensive care unit and were treated with rt-PA. All data were collected prospectively, including birth weight, gestational age, underlying disease, treatment regimen, clot patency, and complications or side effects. 


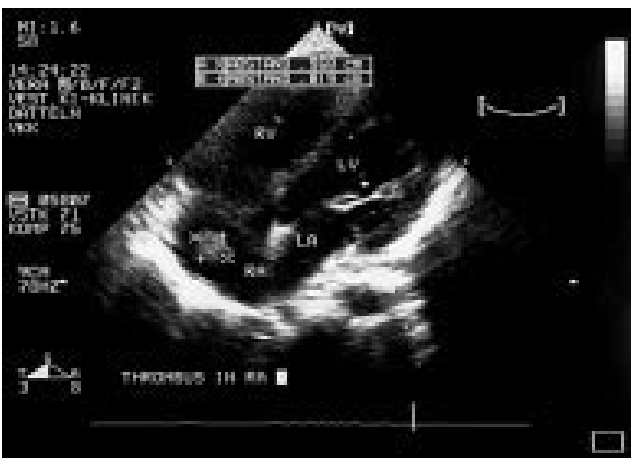

Figure 1 Thrombus formation in the right atrium (four chamber view). RV, Right ventricle; $L V$, left ventricle; $R A$, right atrium; $L A$, left atrium.

Over 30-60 minutes: i.v. bolus of rt-PA $0.7 \mathrm{mg} / \mathrm{kg}$

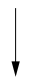

Continuous infusion with: rt-PA $0.2 \mathrm{mg} / \mathrm{kg} / \mathrm{h}+$ heparin 4-10 IU/kg/h

Dose modification: rt-PA 0.1-0.3 mg/kg/h + heparin 4-10 IU/kg/h

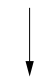

After end of thrombolytic treatment: low dose heparin (2-6 IU/kg/h)

Figure 2 Schedule for thrombolytic treatment with $r t-P A$ in neonatal period. Dose modification depended on the success of the thrombolytic treatment, complications, and coagulation status (see also table 2). Heparin prophylaxis was continued as long as central venous lines were required.

EVALUATION BEFORE TREATMENT AND

CONTRAINDICATIONS

Before initiation of rt-PA treatment, coagulation studies, including prothrombin time, activated partial thromboplastin time, fibrinogen, and fibrin split products, were obtained to evaluate possible bleeding disorders. ${ }^{19}$ Additional studies included complete blood cell counts and detection of protein $C$ or protein $S$ deficiency or activated protein $\mathrm{C}$ resistance and other haemolytic disorders. All patients had a clinical and radiological evaluation to ensure the absence of contraindications, such as acute intracranial, pulmonary, or gastrointestinal bleeding.

RT-PA PROTOCOL

By analysing rt-PA studies in adults, we created the rt-PA protocol given in fig 2. Babies were treated with rt-PA (Actilyse; Boehringer, Ingelheim, Germany) if their parents consented. Coagulation values were measured at least once a day to keep them in the preferred range (table 1). ${ }^{19}$ rt-PA was given intravenously mostly by using a new central line. Sometimes the affected catheter or peripheral venous lines were used.

TREATMENT MONITORING

The effect of the thrombolytic treatment was controlled at least daily by two dimensional echocardiography. Treatment was stopped in the case of total clot lysis, partial clot lysis with only minor clot residue after five days of treatment, or complications, such as general or significant local bleeding or coagulation disorders. To detect organ bleeding, in particular intracerebral bleeding, an ultrasound scan was performed at least twice a week. To control thrombolysis and anticoagulation, haemoglobin, platelet count, prothrombin time, activated partial thromboplastin time, antithrombin III, fibrinogen, and fibrin split products were assayed. To avoid a reoccurrence of thrombosis, after rt-PA treatment low dose heparin treatment was initiated and continued as long as central venous lines were required.

LITERATURE REVIEW

All reports of rt-PA use in neonates found in Medline by the keywords neonates-infantsthrombus formation-thrombolysis-rt-PAurokinase-streptokinase were reviewed. Basic data, thrombus location, rt-PA and heparin dosage regimens, treatment duration, complications, labour findings, and clot outcome were determined as far as possible.

\section{Results}

The diagnosis of CRT was established by two dimensional echocardiography (except for patient 14 (table 2) for whom the diagnosis was made by clinical examination), at an average of 13 days of life (range 3-22) (except for patient 12 , in whom the CRT was detected at the corrected age of 6 months). The latter was included because of extreme immaturity with prolonged growth failure and because he remained in the neonatal intensive care unit.

Neonates with sepsis $(71 \%)$, preterm delivery $(64 \%)$, or respiratory distress syndrome $(57 \%)$, and infants of diabetic mothers (43\%) were most affected (table 2), whereas persistent pulmonary hypertension (29\%), peripartum asphyxia, small size for gestational age (each $21 \%)$, meconium aspiration (14\%), extreme immaturity (birth weight $\leqslant 1000 \mathrm{~g}$ or gestational age $\leqslant 28$ weeks; $14 \%$ ), patent ductus arteriosus, transient tachypnoea, and hypoglycaemia (each $7 \%$ ) were rarer events.

In 10 cases, the precipitating cause was an umbilical venous catheter, in three cases $(21 \%)$ an umbilical artery catheter, and in one case a central venous line.

Complete clot dissolution was documented in 11 patients, and partial clot lysis in two patients; in the first of these, the thrombus had disappeared at the time of discharge, and in the second the thrombus was completely dissolved by 9 months of age. Duration of lysis was on average three days (range one to five). The patency rate was $94 \%$. In one patient (number 4 ), rt-PA administration was discontinued because of local bleeding from various venepuncture sites. In another patient (number 10), treatment had to be interrupted for three hours because of the same minor complications; after the infusion was stopped, the symptoms subsided and reinstitution of rt-PA treatment was successful. Severe complications such as intracranial bleeding were not seen. In patient number 2 , we were able to reduce the rt-PA 
Table 1 Selected values (taken from Weiner et al ${ }^{18}$ ) for components of the coagulation, coagulation inhibitor, and fibrinolytic system in neonates

\begin{tabular}{llll}
\hline \multirow{3}{*}{ Coagulation tests } & \multicolumn{2}{l}{ Reference values } & Preferred values under \\
\cline { 2 - 3 } & Preterm infants & Full term infants & treatment with rt-PA \\
\hline PT (seconds) & $14.6-16.9$ & $11.8-13.0$ & $\sim 30-40$ \\
PT (\%) & $31-48$ & $48-68$ & $\geqslant 40$ \\
aPTT (seconds) & $80-168$ & $40.4-42.9$ & $\sim 50-60$ \\
Fibrinogen (mg/dl) & $160-550$ & $270-312$ & $\geqslant 150$ \\
ATIII (U/ml) & $0.38-0.59$ & $0.62-0.78$ & - \\
ATIII (\%) & $28-38$ & $63-78$ & $\geqslant 50$ \\
Plasminogen (U/ml) & $1.70-1.91$ & $1.95-2.17$ & - \\
\hline
\end{tabular}

The reference values for the preterm infants are values at birth, and those for the full term infants are mean values during the first month of life. rt-PA treatment was monitored only by PT (in seconds and \%), aPTT, ATIII (\%), fibrinogen, and fibrin split products.

PT, Prothrombin time; aPTT, activated partial thromboplastin time; ATIII, antithrombin III rt-PA, recombinant tissue plasminogen activator.

dose on the second day of treatment because of rapid clot lysis, and in five patients the dose had to be increased by the use of a repeated bolus (patients 9 and 14), a higher dosage (patients 6, 8 , and 9), or a second infusion protocol (patient 12).

Coagulation was successfully prolonged in 11 cases; in patient 14 lysis had to be interrupted three times because of low fibrinogen levels, but was finished successfully. In patient 8 , antithrombin III had to be substituted. In addition, coagulation studies showed a modest decrease in fibrinogen concentration $(100-150 \mathrm{mg} / \mathrm{dl})$ in seven cases; a transient abnormal elongated prothrombin time and activated partial thromboplastin time were seen in a couple of patients, but all values were restored to normal after treatment was finished. Neither severe bleeding complications, such as intracranial haemorrhage, nor other side effects, such as allergic reaction to the thrombolytic agent, were observed.

\section{Discussion}

The thrombotic risk of central lines used in neonates $^{7-9}$ and the pathophysiology of thrombogenesis ${ }^{211} 20-23$ have been extensively reported. Since the use of central catheters in neonates, CRT is an increasingly observed complication, ${ }^{4-7} 20$ and, although overall it is still rare, in major neonatal units it is increasing.

Effective and safe thrombolytic treatment is essential in the management of neonates and infants with life threatening thrombosis. Efficient thrombolytic agents available are streptokinase, urokinase, and rt-PA. Administration of streptokinase has been abandoned because of its antigenic qualities, relatively long half time (20-30 minutes), and systemic side effects. ${ }^{24}$ Nowadays, rt-PA is commonly recommended, because of its short half time (about five minutes), non-antigenic qualities, and local specific action on plasminogen bound fibrin. ${ }^{25}$

Table 2 Clinical data

\begin{tabular}{|c|c|c|c|c|c|c|}
\hline Patient No & $\begin{array}{l}\text { Gestational age } \\
\text { (weeks) } \\
\text { Birth weight (g) }\end{array}$ & Underlying disease & $\begin{array}{l}\text { Thrombus (locus and day of life) } \\
\text { Central line }\end{array}$ & $\begin{array}{l}\text { rt-PA bolus }(\mathrm{mg} / \mathrm{kg}) / \\
\text { therapy (mg/kg/day)/ } \\
\text { duration (days) }\end{array}$ & $\begin{array}{l}\text { Heparin dose } \\
\text { (IU/kg/day) } \\
\text { Prophylaxis } \\
\text { (doselduration) }\end{array}$ & $\begin{array}{l}\text { Clot outcome } \\
\text { Complications }\end{array}$ \\
\hline 1 & $\begin{array}{l}32 \\
2200\end{array}$ & $\begin{array}{l}\text { IDM } \\
\text { neonatal sepsis }\end{array}$ & $\begin{array}{l}\text { In right atrium at day } 9 \\
\text { UVC }\end{array}$ & $0.7 / 0.2 / 4$ & $\begin{array}{l}100 \\
100 / 10\end{array}$ & $\begin{array}{l}+ \\
\text { None }\end{array}$ \\
\hline 2 & $\begin{array}{l}40 \\
5360\end{array}$ & $\begin{array}{l}\text { IDM } \\
\text { hypoglycaemia }\end{array}$ & $\begin{array}{l}\text { In right atrium at day } 8 \\
\text { UVC }\end{array}$ & $0.7 / 0.2 \rightarrow 0.1 / 2$ & $\begin{array}{l}150 \\
100-50 / 5\end{array}$ & $\stackrel{+}{\text { None }}$ \\
\hline 3 & $\begin{array}{l}35 \\
1980\end{array}$ & IDM, RDS & $\begin{array}{l}\text { In right atrium at day } 21 \\
\text { UVC }\end{array}$ & $0.7 / 0.2 / 1$ & $\begin{array}{l}250 \\
100 / 5\end{array}$ & $\stackrel{+}{\text { None }}$ \\
\hline 4 & $\begin{array}{l}37 \\
4300\end{array}$ & $\begin{array}{l}\text { IDM } \\
\text { transient tachypnoea }\end{array}$ & $\begin{array}{l}\text { In right atrium at day } 10 \\
\text { UVC }\end{array}$ & $0.7 / 0.2 / 2$ & $\begin{array}{l}150 \\
\text { None }\end{array}$ & $\overline{\text { Local bleeding }}$ \\
\hline 5 & $\begin{array}{l}35 \\
3040\end{array}$ & $\begin{array}{l}\text { RDS, PPHN } \\
\text { neonatal sepsis }\end{array}$ & $\begin{array}{l}\text { In aorta at day } 15 \\
\text { UVC and UAC }\end{array}$ & $0.7 / 0.2 / 1$ & $\begin{array}{l}150 \\
100 / 2\end{array}$ & $\stackrel{+}{\text { None }}$ \\
\hline 6 & $\begin{array}{l}40 \\
3450\end{array}$ & $\begin{array}{l}\text { peripartal asphyxia } \\
\text { PPHN, neonatal sepsis }\end{array}$ & $\begin{array}{l}\text { In aorta at day } 22 \\
\text { UVC and UAC }\end{array}$ & $0.7 / 0.2 \rightarrow 0.3 / 3$ & $\begin{array}{l}150 \\
100 / 7\end{array}$ & $\stackrel{+}{\text { None }}$ \\
\hline 7 & $\begin{array}{l}30 \\
1190\end{array}$ & $\begin{array}{l}\text { RDS, PDA } \\
\text { neonatal sepsis }\end{array}$ & $\begin{array}{l}\text { In left atrium at day } 12 \\
\text { UVC and UAC }\end{array}$ & $0.7 / 0.2 / 1$ & $\begin{array}{l}150 \\
100 / 5\end{array}$ & $\stackrel{+}{\text { None }}$ \\
\hline 8 & $\begin{array}{l}33 \\
1450\end{array}$ & $\begin{array}{l}\text { SGA, RDS } \\
\text { neonatal sepsis }\end{array}$ & $\begin{array}{l}\text { In right atrium at day } 19 \\
\text { UVC }\end{array}$ & $0.7 / 0.2 \rightarrow 0.3 / 2$ & $\begin{array}{l}250 \\
100 / 1\end{array}$ & $\begin{array}{l}(+) \\
\text { AT3-deficiency }\end{array}$ \\
\hline 9 & $\begin{array}{l}3 \\
1315\end{array}$ & $\begin{array}{l}\text { IDM, RDS } \\
\text { neonatal sepsis }\end{array}$ & $\begin{array}{l}\text { In right atrium at day } 6 \\
\text { UVC }\end{array}$ & $\begin{array}{l}0.7(2 \text { times }) / \\
0.2 \rightarrow 0.3 \rightarrow 0.2 / 5\end{array}$ & $\begin{array}{l}150 \\
100 / 7\end{array}$ & $\stackrel{+}{\text { None }}$ \\
\hline 10 & $\begin{array}{l}42 \\
4550\end{array}$ & $\begin{array}{l}\text { Peripartal asphyxia } \\
\text { IDM, MAS, PPHN } \\
\text { neonatal sepsis }\end{array}$ & $\begin{array}{l}\text { In right atrium at day } 16 \\
\text { UVC }\end{array}$ & $0.7 / 0.2 / 4$ & $\begin{array}{l}100 \\
100-50 / 5\end{array}$ & $\stackrel{+}{\text { Local bleeding }}$ \\
\hline 11 & $\begin{array}{l}40 \\
1900\end{array}$ & $\begin{array}{l}\text { RDS, SGA } \\
\text { neonatal sepsis }\end{array}$ & $\begin{array}{l}\text { In right atrium at day } 14 \\
\text { UVC }\end{array}$ & $0.7 / 0.2 / 3$ & $\begin{array}{l}200 \\
150-100 / 4\end{array}$ & $\begin{array}{l}+ \\
\text { None }\end{array}$ \\
\hline 12 & $\begin{array}{l}24 \\
585\end{array}$ & $\begin{array}{l}\text { RDS, IVH } \\
\text { neonatal sepsis }\end{array}$ & $\begin{array}{l}\text { In right atrium (6th month) } \\
\text { CVL and VAS }\end{array}$ & $0.7 / 0.2 / 4$ (2 times $)$ & $\begin{array}{l}100 \\
150-50 / 6\end{array}$ & $\stackrel{+}{\text { None }}$ \\
\hline 13 & $\begin{array}{l}41 \\
4200\end{array}$ & $\begin{array}{l}\text { Peripartal asphyxia } \\
\text { MAS, PPHN }\end{array}$ & $\begin{array}{l}\text { In right atrium at day } 21 \\
\text { UVC }\end{array}$ & $0.7 / 0.2 / 4$ & $\begin{array}{l}150 \\
150-100 / 4\end{array}$ & $\begin{array}{l}(+) \\
\text { None }\end{array}$ \\
\hline 14 & $\begin{array}{l}27 \\
750\end{array}$ & $\begin{array}{l}\text { RDS, SGA } \\
\text { neonatal sepsis }\end{array}$ & $\begin{array}{l}\text { In aorta at day } 3 \\
\text { UVC and UAC }\end{array}$ & $\begin{array}{l}0.7 \text { (3 times)/ } \\
0.2 / 3 \text { (interrupted) }\end{array}$ & $\begin{array}{l}200 \text { (interrupted) } \\
100-50 / 2\end{array}$ & $\begin{array}{l}+ \\
\text { None }\end{array}$ \\
\hline
\end{tabular}

rt-PA, Recombinant tissue plasminogen activator; IDM, infants of diabetic mothers; RDS, respiratory distress syndrome; PPHN, persistent pulmonary hypertension; PDA, patent ductus arteriosus; SGS, small for gestational age; MAS, meconium aspiration; IVH, intraventricular haemorrhage; UVC, umbilical venous catheter; UAC, umbilical artery catheter, CVL, central venous line; VAS, ventricular-atrial shunt. 
Table 3 Literature review (Medline) on recombinant tissue plasminogen activator (rt-PA) treatment in neonatal period

\begin{tabular}{|c|c|c|c|c|c|c|}
\hline \multirow[b]{2}{*}{ Author } & \multirow[b]{2}{*}{ No of patients } & \multicolumn{3}{|l|}{$r t-P A$ dose } & \multirow[b]{2}{*}{ Clot outcome } & \multirow[b]{2}{*}{ Complications/side effects } \\
\hline & & Bolus (mg/kg) & Infusion $(\mathrm{mg} / \mathrm{kg} / \mathrm{h})$ & Duration (h) & & \\
\hline \multicolumn{7}{|l|}{ Small series } \\
\hline Anderson $^{13}$ & 4 & None & 0.05 & $96-240$ & Complete 3 & IVH, rethrombosis \\
\hline Dillon $^{14}$ & 3 & 0.5 & $0.04-0.08$ & 58 & Complete & Local bleeding \\
\hline Nowak-Göttl ${ }^{12} 1642 \star$ & 19 & $0.1-0.75$ & $0.03-0.375$ & $0.5-240$ & $\begin{array}{l}\text { Complete } 15 \\
\text { Partial } 3\end{array}$ & $\begin{array}{l}\text { Rethrombosis, local and significant } \\
\text { bleeding, IVH }\end{array}$ \\
\hline Farnoux $^{15} \dagger$ & 16 & 0.1 & 0.3 & 3 & $\begin{array}{l}\text { Complete } 7 \\
\text { Partial } 7\end{array}$ & 1 deadly bleeding \\
\hline Weiner $^{17}$ & 7 & None & $0.1-0.5$ & $6-39$ & $\begin{array}{l}\text { Complete } 4 \\
\text { Partial } 2\end{array}$ & Severe bleeding \\
\hline \multicolumn{7}{|l|}{ Single cases } \\
\hline Zenz & 2 & $0.1-0.5$ & 0.25 & $4-9$ & $\begin{array}{l}\text { Complete } 1 \\
\text { Partial } 1\end{array}$ & Local and renal bleeding \\
\hline Trowitzsch & 1 & 0.3 & 0.2 & 7 & Complete & None \\
\hline Kennedy & 1 & None & 0.47 & 3 & Complete & Amputation of toes \\
\hline Levy $\ddagger$ & 2 & None & 0.47 & $2-72$ & Complete & Local bleeding \\
\hline Deeg & 1 & None & 0.5 & 3 & Partial & IVH extension \\
\hline Van Overmeire & 1 & 0.5 & 0.2 & 48 & Complete & None \\
\hline Schneider & 1 & 0.1 & 0.2 & 6 & Complete & None \\
\hline Guerin & 2 & None & $0.05-0.2$ & $12-24$ & Complete & None \\
\hline Berger & 2 & 0.1 & 0.3 & 3 & Complete & None \\
\hline $\operatorname{Ries} \rrbracket$ & 1 & $0.1-0.2$ & $0.03-0.06$ & 34 & Complete & None \\
\hline Thulø & 1 & 0.2 & 0.4 & 2 & Complete & Bleeding \\
\hline Ahluwalia & 1 & None & 0.5 & 10 & Complete & None \\
\hline Smets & 2 & None & $0.1-0.4$ & $48-264$ & Partial & Significant bleeding \\
\hline Seibold-Weiger & 1 & None & 0.08 & 12 & No lysis & Extensive bleeding \\
\hline Kandler & 1 & 0.4 & 0.02 & 36 & Complete & None \\
\hline Daoud & 1 & 0.1 & 0.3 & 3 & Complete & None \\
\hline Torkington ${ }^{\star \star}$ & 1 & 0.15 & $0.3-0.75$ & 3 & Complete & NEC \\
\hline Giuffre & 2 & None / 1 & $0.5-1$ & $4-6$ & Complete & None \\
\hline Grieg & 1 & None & 1 & 15 & Complete & None \\
\hline Di Bernado & 1 & 0.3 & 0.3 & 16 & Partial & IVH, bleeding \\
\hline Krienke & 2 & $0.3-0.5$ & $0.02-0.04$ & $8-64$ & $\begin{array}{l}\text { Complete } 1 \\
\text { Partial } 1\end{array}$ & None \\
\hline Glover & 1 & 0.48 & 0.27 & 6 & Complete & IVH \\
\hline Klinget† & 1 & 0.01 & None & - & Partial & Vascular spasm \\
\hline Malm & 1 & 0.05 & None & - & Complete & IVH \\
\hline$\Sigma$ & 80 & $0-0.75$ & $0.02-1$ & $1 / 2-264$ & $\begin{array}{l}\text { Complete } 55 \\
\text { Partial } 20\end{array}$ & $\begin{array}{l}\text { Local to severe bleeding, rethrombosis, } \\
\text { amputation, vascular spasm }\end{array}$ \\
\hline Own collection & 14 & 0.7 & $(0.1-) 0.2(-0.3)$ & $24-120$ & $\begin{array}{l}\text { Complete } 11 \\
\text { Partial } 2\end{array}$ & Local bleeding \\
\hline
\end{tabular}

Only data of reports with complete information were included. Requests for entire literature list of single cases to jhartmann@hdz-nrw.de. The bolus was a short infusion (10-60 minutes).

${ }^{\star}$ Data collection was performed as a meta-analysis of all reports; †up to four additional rt-PA infusions were given at intervals of $12-24$ hours; $\ddagger$ only data of neonates were reviewed; Sbolus infusion was repeated twice with $0.1 \mathrm{mg} / \mathrm{kg}$ and twice with $0.2 \mathrm{mg} / \mathrm{kg}$ followed by continuous infusion of $0.06 \mathrm{mg} / \mathrm{kg} / \mathrm{h}$ for $16 \mathrm{hours}$ and $0.03 \mathrm{mg} / \mathrm{kg} / \mathrm{h}$ for 18 hours; ๆregimen was repeated after 12 hours; ${ }^{\star \star} 1.5 \mathrm{mg} / \mathrm{kg}$ once a day, $10 \%$ as bolus, $50 \%$ as infusion over one hour and $40 \%$ as infusion over two hours, repeated on six days; $+\dagger$ bolus dose was repeated 3 times.

IVH, Intraventricular haemorrhage; NEC, necrotising enterocolitis.

There are established protocols for fibrinolytic treatment with rt-PA in adults, ${ }^{26} 27$ and the efficacy of thrombolysis in childhood has been documented. ${ }^{28-30}$

However, there is still very little experience with fibrinolytic treatment in the neonatal period. Treatment for neonatal thrombosis remains controversial, guidelines are available but rare, ${ }^{12} 23-31$ and randomised double blinded trials are still lacking. Therefore many doctors follow adult guidelines. ${ }^{32-35}$ Table 3 gives an overview of studies focusing on thrombolytic treatment with rt-PA in neonatal arterial and venous diseases, including CRT and spontaneous thrombotic disease. The overall patency rate of $94 \%$ (68\% for complete clot dissolution and $26 \%$ for partial clot dissolution) is comparable with our experience ( $94 \%$ patency rate: $79 \%$ complete clot dissolution and $14 \%$ partial clot dissolution). Comparison of the reports of a low dose rt-PA regimen $(0.02-0.08 \mathrm{mg} / \mathrm{kg} /$ h) ${ }^{36}{ }^{37}$ with those of a high dose regimen $(0.1-1$ $\mathrm{mg} / \mathrm{kg} / \mathrm{h})^{12} 293839$ shows an apparently significant difference in patency rate ( $81 \% v 95 \%)$, although in the first group an initial bolus was given. In both groups, complications ranged from none to severe, but, for both patency rate and complications, data collection was too random to draw any conclusions.

Another comparison between bolus or no bolus shows interesting results. Whereas in the bolus group $95 \%$ of the patients were detected with positive clot outcome (39 of 56 patients (70\%) with complete, and 25 of 56 patients (25\%) with partial, clot dissolution), in the no bolus group only $88 \%$ (16 of $23(67 \%$ ) with complete, and 5 of $24(21 \%)$ with partial, clot dissolution) showed an effect. Again, the groups are very small and bolus dose varies widely, so that conclusions should be made carefully. However, these results seem to justify an rt-PA bolus before continuous infusion.

In addition, thrombosis prophylaxis with low dose heparin is widely recommended, but the administration of heparin is controversial and the different regimens ranged from no heparin to low dose to high dose treatment during thrombolytic treatment. In most reports, administration of low dose heparin (an average of $5 \mathrm{IU} / \mathrm{kg} / \mathrm{h}$ ) was recommended. Statistical analysis of this data collection gives no further information about suitable thrombolytic treatment in the neonatal period because of 
inhomogeneous and incomplete data collection in several reports. Nevertheless, thrombolytic treatment with rt-PA combined with low dose heparin administration seems to be very efficient and safe.

There are still some reports of the successful use of urokinase $\mathrm{e}^{40-44}$ and even streptokinase $\mathrm{e}^{36}$ for thrombotic disease in the neonatal period. Randomised double blind trials, based on results from adult patients, have led to the recommendation that rt-PA should be used on the one hand $\mathrm{d}^{37}$ and equal benefits for rt-PA and urokinase $^{40}$ on the other. rt-PA seems to act faster and to have more side effects. ${ }^{40}$ Interestingly, several authors ${ }^{419}{ }^{39}$ reported successful rt-PA treatment after insufficient trials with urokinase.

Reports differ with regard to the incidence of complications. ${ }^{14} 3138$ In our experience, severe complications were rare and intracerebral haemorrhage did not occur. This is in agreement with other reports. ${ }^{45}$

To summarise, the literature does not provide enough information to enable recommendations to be made about rt-PA use in the newborn. The present rt-PA protocol with high dose infusion after an initial bolus seems to be an efficient and safe conservative procedure for neonatal clot dissolution. Although a homogeneous collection of cases has been presented, the study has several limitations. However, we feel that these promising results can be used as a starting point for further investigation.

1 Coon W, Willis P, Keller J. Venous thrombembolism and other venous diseases in the Tecumseh Healthy Study. Cirother venous diseases
culation 1993;48:839.

2 Andrew M. Developmental hemostasis: relevance to thromboembolic complications in pediatric patients. thromboembolic complications

3 Nowak-Göttl U, Kries von R, Göbel U. Neonatal symptomatic thromboembolism in Germany: two year survey Arch Dis Child 1997;76: F163-7.

4 Schmidt B, Andrew M. Neonatal thrombosis: report of a prospective canadian and international registry. Pediatric 1995;96:939-43.

5 Berman W, Fripp RR, Yabek SM. Great vein and right atrial thrombosis in critically ill infants and children with central venous lines. Chest 1991;99:963-96.

6 Manco-Johnson MJ. Disorders of hemostasis in childhood: risk factors for venous thromboembolism. Thromb Haemost 1997;78:710-14.

7 Metha S, Connors A, Danish EH, et al. Incidence of thrombosis during central venous catheterization of newborns: a prospective study. F Pediatr Surg 1992;27:18-22.

8 Tanke RB, Mengen van R, Daniels O. Thrombus detection on central venous catheters in the neonatal intensive care unit. Angiology 1994;45:477-80.

9 Schiff DE, Stonestreet BS. Central venous catheters in low birth weight infants: incidence of related complications. $\mathscr{f}$ Perinatol 1993;13:153-8.

10 Hausler M, Duque D, Merz U, et al. The clinical outcome after inferior vena cava thrombosis in early infancy. Eur $\mathscr{f}$ Pediatr 1999;158:416-20.

11 Michelson AD, Bovill E, Andrew M. Antithrombotic therapy in children. Fourth ACCP consensus conference on antithrombotic therapy. Chest 1995;108(suppl):506S $22 \mathrm{~S}$

12 Nowak-Göttl U, Auberger K, Halimeh S, et al. Thrombolysis in newborns and infants. Thromb Haemost 1999;82(suppl):112-16.

13 Nowak-Göttl U, Kreuz W, Schwabe D, et al. Thrombolysis with rt-PA in children suffering from arterial or venous with rt-PA in children suffering from arte.

14 Anderson BJ, Keeley SR, Johnson ND. Caval thrombolysis in neonates using low doses of recombinant human tissuein neonates using low doses of recombinant human tissuetype plasmin
$1991 ; 19: 22-7$.

15 Dillon PW, Fox PS, Berg CJ, et al. Recombinant tissue plasminogen activator for neonatal and pediatric vascular thrombolytic therapy. $\mathcal{F}$ Pediatr Surg 1993;28:1264-9. 16 Farnoux C, Camard O, Pinquier D, et al. Recombinant tissue-type plasminogen activator therapy of
in 16 neonates. 7 Pediatr $1998 ; 133: 137-40$.

17 Nowak-Göttl U, Schwabe D, Schneider W, et al. Thrombolysis with recombinant tissue-type plasminogen activator in renal venous thrombosis in infancy. Lancet 1992;340:1105.

18 Weiner GM, Castle VP, DiPietro MA, et al. Successful treatment of neonatal arterial thromboses with recombinant tissue plasminogen activator. F Pediatr 1998;133:133-6.

19 Andrew M, Brooker LA. Hemostatic disorders in newborns. In: Taeusch HW, Ballard RA, eds. Avery's diseases of the newborn. 7th ed. Philadelphia: WB Saunders, 1998:104579.

20 Manco-Johnson MJ. Diagnosis and management of thrombosis in the perinatal period. Semin Perinatol 1990;14:393402

21 Kothari SS, Varma S, Wasir HS. Thrombolytic therapy in infants and children. Am Heart $\mathcal{F}$ 1994;127:651-7.

22 Trusen B, Ries M, Zenker M, et al. Whole blood clot lysis in newborns and adults after adding different concentrations of recombinant tissue plasminogen activator (rt-PA). Semin Thromb Hemost 1998;24:599-604.

23 Andrew M, Michelson AD, Bovill E, et al. Guidelines for antithrombotic therapy in pediatric patients. $f$ Pediatr 1998;123:575-88.

24 Andrew M, Brooker L, Leaker M. Fibrin clot lysis by thrombolytic agents is impaired in newborns due to a low plasminogen concentration Thromb Haemost 1992;68:325-

25 Holden RW. Plasminogen activators: pharmacology and therapy. Radiology 1990;174:993-1001

26 Nayler CD, Armstrong PD. Guidelines for the use of intravenous thrombolytic agents in acute myocardial infarction. Can Med Assoc F 1989;140:1289-90.

27 Marder VJ. Thrombolytic therapy: current status (two parts). N Engl f Med 1988;318:1512-20 (first part), 1585-95 (second part).

28 David M, Manco-Johnson M, Andrew M. Diagnosis and treatment of venous thrombembolism in children and treatment of venous thrombembolism in

29 Doyle E, Britto J, Freeman J, et al. Thrombolysis with low dose tissue plasminogen activator. Arch Dis Child 1992;67:1483-4.

30 Schmidt B, Andrew M. Report of scientific and standardization subcommittee on neonatal hemostasis. Diagnosis and treatment of neonatal thrombosis. Thromb Haemost 1992;67:381-2.

31 Zenz W, Muntean W. Thrombolytic therapy in children: an update. Fibrinolysis 1995;9(suppl):33-6.

32 Ahluwalia JS, Kelsall WAR, Diederich S, et al. Successful treatment of aortic thrombosis after umbilical catheterization with tissue plasminogen activator. Acta Paediatr 1994;83:1215-17.

33 Deeg, KH, Wolfel D, Rupprecht T. Diagnosis of neonatal aortic thrombosis by colour coded Doppler sonography. Pediatr Radiol 1992;22:62-3.

34 Kennedy LA, Drummond WH, Knight ME, et al. Successsful treatment of neonatal aortic thrombosis with tissue plasminogen activator. F Pediatr 1990;116:798-801.

35 Levy M, Benson LN, Burrows Ps, et al. Tissue plasminogen activator for the treatment of thromboembolism in infants and children. F Pediatr 1991;118:467-72.

36 Rehan VK, Cronin CM, Bowman JM. Neonatal portal vein thrombosis successfully treated by regional streptokinase infusion. Eur f Pediatr 1994;153:456-9.

37 Haire WD, Atkinson JB, Stephens LC, et al. Urokinase versus recombinant tissue plasminogen activator in thrombosed central venous catheters: a double-blinded, randomized trial. Thromb Haemost 1994;72:543-7.

38 Leaker M, Massicotte P, Brokker LA, et al. Thrombolytic therapy in pediatric patients: a comprehensive review of the literature. Thromb Hemost 1996;76:132-4.

39 Atkinson JB, Bagnall HA, Gomperts E. Investigational use of tissue plasminogen activator (t-PA) for occluded central venous catheters. F Parenter Enteral Nutr 1990;14:310-11.

40 Cina CS, Raymond HG, Chan J, et al. Intrarterial catheterdirected thrombolysis: urokinase versus tissue plasminogen activator. Ann Vasc Surg 1999;13:571-5.

41 Colnaghi C, Cazzuffi MA, Introvini $\mathrm{P}$, et al. Urokinase in a premature infant: its use in a case of right atrial thrombosis secondary to catheterization of the umbilical vein. Pediatr Med Chir 1995;17:275-7.

42 Giacoia GP. High-dose urokinase therapy in newborn infants with major vessel thrombosis. Clin Pediatr (Phila) 1993;32:231-7.

43 Wever MLG, Liem KD, Geven WB, et al. Urokinase therapy in neonates with catheter related central venous thrombosis. Thromb Haemost 1995;73:180-5.

44 Aspesberro F, Beghetti M, Oberhansli I, et al. Local low-dose urokinase of acquired intracardiac thrombi in preterm infants. Eur f Pediatr 1999;158:698-701.

45 Zenz W, Arlt F, Sodia S, et al. Intracerebral hemorrhage during fibrinolytic therapy in children: a review of the literature of the last thirty years. Semin Thromb Hemost 1997;23:321-32. 